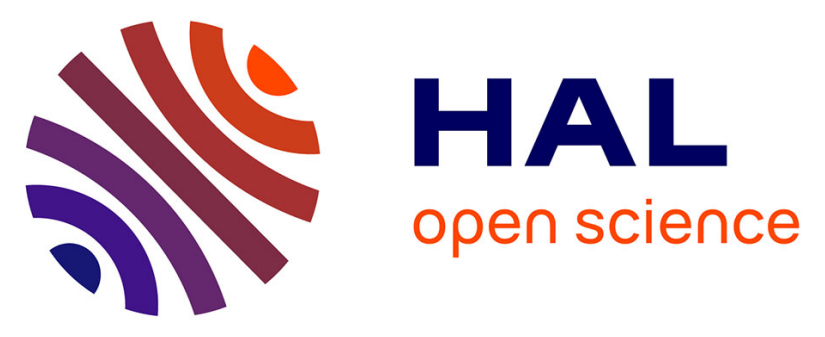

\title{
Isolation of volatils from maritime pine sawdust waste by different processes: Ultrasound, microwave, turbohydrodistillation, and hydrodistillation
}

\author{
Alice Meullemiestre, Emmanuel Petitcolas, Zoulikha Maache-Rezzoug, \\ Christian Ginies, Farid Chemat, Sid-Ahmed Rezzoug
}

\section{To cite this version:}

Alice Meullemiestre, Emmanuel Petitcolas, Zoulikha Maache-Rezzoug, Christian Ginies, Farid Chemat, et al.. Isolation of volatils from maritime pine sawdust waste by different processes: Ultrasound, microwave, turbohydrodistillation, and hydrodistillation. Wood Material Science and Engineering, 2014, 9 (2), pp.76-83. 10.1080/17480272.2014.881915 . hal-02640071

\section{HAL Id: hal-02640071 \\ https://hal.inrae.fr/hal-02640071}

Submitted on 28 May 2020

HAL is a multi-disciplinary open access archive for the deposit and dissemination of scientific research documents, whether they are published or not. The documents may come from teaching and research institutions in France or abroad, or from public or private research centers.
L'archive ouverte pluridisciplinaire HAL, est destinée au dépôt et à la diffusion de documents scientifiques de niveau recherche, publiés ou non, émanant des établissements d'enseignement et de recherche français ou étrangers, des laboratoires publics ou privés. 


\title{
Isolation of volatils from maritime pine sawdust waste by different processes: Ultrasound, microwave, turbohydrodistillation, and hydrodistillation
}

\author{
ALICE MEULLEMIESTRE ${ }^{1}$, EMMANUEL PETITCOLAS ${ }^{2}$,

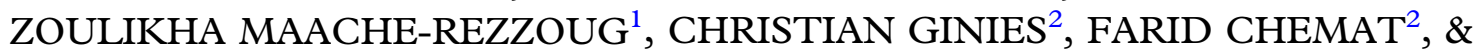 \\ SID-AHMED REZZOUG ${ }^{1 \star}$ \\ ${ }^{1}$ LASIE, UMR CNRS 7356, Université de La Rochelle, La Rochelle, France, ${ }^{2}$ GREEN Extraction Team, INRA, UMR 408, \\ Université d'Avignon et des Pays de Vaucluse, Avignon, France
}

\begin{abstract}
This study concerns the transformation of maritime pine (Pinus pinaster) sawdust waste into potentially novel products through isolation of volatile compounds in the form of valuable oil. Different techniques, namely, turbohydrodistillation (THD), solvent-free microwave extraction (SFME), microwave hydrodiffusion and gravity (MHG), and ultrasound-assisted extraction (UAE) were tested. These different processes were compared to conventional hydrodistillation (HD) and allowed to extract almost similar yields of isolated oils. THD which consists in a permanent agitation during extraction and UAE improve the kinetics of extraction, but MHG and SFME required the shortest extraction times, 60 min to reach a maximal yield of 0.272 and $0.266 \%(\mathrm{w} / \mathrm{w})$, respectively. The compositions of isolated oils are almost similar with a high proportion of oxygenated compounds for MHG and SFME, respectively, 56.9\% and 54.5\% compared with $37.7 \%$, $44.1 \%$ and $34.1 \%$, respectively, for THD, UAE, and for the conventional HD method.
\end{abstract}

Keywords: Extraction, maritime pine wood, volatile compounds, hydrodistillation, microwaves-assisted extraction, ultrasound-assisted extraction

\section{Introduction}

Nowadays, there is a growing interest in procurement of wood-based goods produced in sustainable environmental manner. In Poitou-Charentes Region (France), more than $5 \times 10^{5}$ tons of wood waste is generated per year of which $10^{5}$ tons are considered as "available." Maritime pine (Pinus pinaster) is a conifer native to Southwestern Europe and Northwestern Africa, with major forests development on Atlantic Coast of southern France, Spain, and Portugal (Seabra et al. 2012). Oils from plants as pine trees are used as natural fragrances in cosmetics, flavoring additives in foods, and beverage. They are also used as intermediate in the synthesis of perfume chemicals and for unconventional medicinal purposes as well as in aromatherapy (Lazutka et al. 2001, Sacchetti et al. 2005). The recovery of value-added chemicals from maritime pine bark (Willför et al. 2009) or needles (Rezzoug 2009) was largely studied, but there are few articles on wood sawdust waste which can be considered as renewable and low-cost product. These types of "green" materials should be gradually in competition with their synthetic counterparts, more expensive and less environmentally friendly. Conventional isolation methods have some disadvantages. For steam distillation and hydrodistillation (HD), high-temperatures and/or long-processing time can cause chemical modifications of oil components and a loss of the most volatile compounds (Khajeh et al. 2004). Similarly, solvent extraction which also undergoes extensive loss of volatile compounds during removal is unable to yield a solvent-free product (Rodríguez-Rojo et al. 2012). In recent years, there has been an increasing demand for new

^Correspondence: S.-A. Rezzoug, LaSIE, Université de La Rochelle, FRE-CNRS 3474 - Pôles Sciences et Technologie, Avenue Michel Crépeau, 17042 La Rochelle, France, Tel: +33 546458615, Fax: +33 546458241. E-mail: sarezzou@univ-lr.fr 
greener techniques for the extraction from various substrates. These innovative green processes must be more environmentally friendly with shorter extraction times, less consumption of organic solvent and energy, and reduced waste and $\mathrm{CO}_{2}$ emissions, while maintaining a high quality of extracts. Supercritical Fluid Extraction leads to high-quality and solvent-free extracts (Fornari et al. 2012). However, the technological conditions required can be onerous due to the high processing pressures (Vemavarapu et al. 2005, Mazzutti et al. 2012), and some studies (Moldão-Martins et al. 2000, Marongiu et al. 2006, Priscilla et al. 2011) have shown that supercritical $\mathrm{CO}_{2}$ fluid not only extracts volatile molecules but also other undesirable compounds such as waxes or resins. The aim of this work was to screen different intensified extraction techniques in order to extract valuable volatile compounds from maritime pine wood waste. Classical HD was compared to the same method intensified by the presence of strong agitation and cutting during extraction. This technique termed as "turbohydrodistillation" is particularly efficient with hard matrixes such as wood, bark, and seeds (Périno-Issartier et al. 2010). The second technique used was Solvent-Free Microwave-assisted Extraction (SFME). It is well known that microwave-assisted techniques are very useful in higher yield extraction, requiring shorter treatment times, and yielding a high extracts quality (Lucchesi et al. 2007, Sahraoui et al. 2008). Although, numerous publications have been reported on using different substrates including citrus by-products (Sahraoui et al. 2011), lavender (Chemat et al. 2006, Farhat et al. 2009), or less-known plants such as Zygophyllum album L., (Tigrine-Kordjani et al. 2011), but none about isolation of volatiles from wood sawdust, in general, and maritime pine sawdust, in particular. The third method tested was microwave hydrodiffusion and gravity (MHG) designed and patented by Chemat et al. (2008) team as a valid alternative to SFME method. This technique combines heating by microwaves and gravity at atmospheric pressure, which allows the extract (water and isolated oil) to diffuse within the material and to drop out of the microwave reactor (Abert-Vian et al. 2008). The last tested technique is ultrasoundassisted extraction (UAE). Ultrasonication is reported to attack the integrity of plant cell walls, resulting in the release of volatiles and the most accessible polysaccharides as well as release of less extractable cell wall components (Shirsatha et al. 2012). Ultrasound also offers a mechanical effect, allowing greater penetration of solvent (water) into the sample matrix, increasing the contact surface area between the solid and the liquid phases, and as a result, the solute diffuses more rapidly from the solid phase into the solvent. In this study, the feasibility of these different extraction techniques for extraction of valuable isolated oil from maritime pine sawdust waste was investigated. For each technique, the kinetics of oil isolation was investigated, the composition of oil was determined, and the microstructure of residual material was evaluated by specific surface area measurement.

\section{Materials and methods}

\subsection{Raw material}

In a recent study on the effect of thickness on isolation of volatiles from oak wood (Mellouk et al. 2013), we showed that the yield of isolated oil is strongly dependent on the sample thickness which influences negatively the yield. In this study, the form of maritime pine ( $P$. pinaster) sawdust (Figure 1$)$ was approximately $(40 \times 3.5 \times 0.5 \mathrm{~mm})$. These sawdust wastes came from the trees in southern France after wood sawmilling by Archimbaud Company (Secondigné/Belle, France). Moisture content was measured by halogen Moisture Analyzer using IR radiations (Ohaus - MB 35) at $105^{\circ} \mathrm{C}$ and corresponded to $43 \%$ dry basis (db). The sawdust waste material was stored in a refrigerated room at $4{ }^{\circ} \mathrm{C}$ and treated in one week following recovery.

\subsection{Extraction methods}

2.2.1 Procedure and apparatus of HD method. Conventional HD apparatus (Clevenger-type) according to the European Pharmacopeia (2012) was employed. A quantity of $500 \mathrm{~g}$ of sawdust for $9 \mathrm{~L}$ of distilled water was used to perform HD for $480 \mathrm{~min}$ from the first drop of distillate fall until the raw material has been completely exhausted. Isolated oil was collected, dried over anhydrous sodium sulfate, and stored at $4^{\circ} \mathrm{C}$ until further analysis. Each extraction

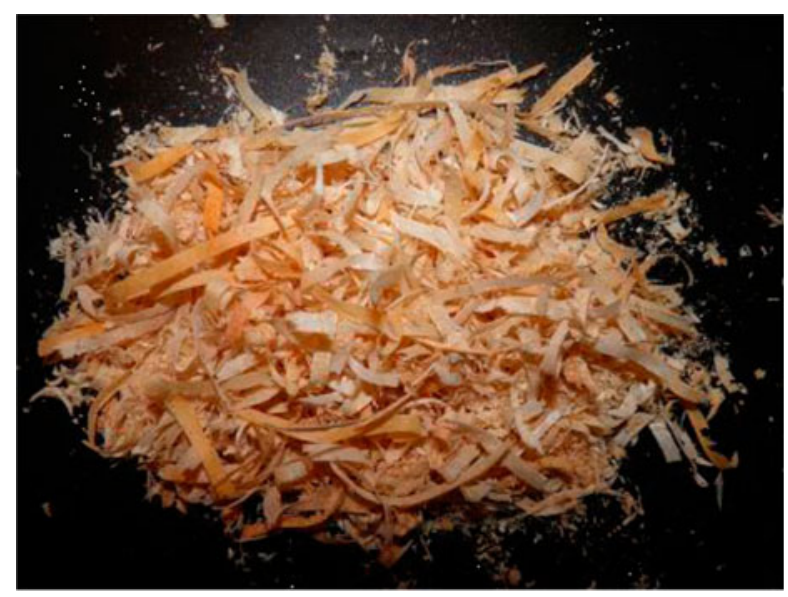

Figure 1. Maritime pine (P. pinaster) sawdust waste. 
was performed at least three times and a standard deviation was calculated.

2.2.2 Procedure and apparatus of THD. THD was performed using a Clevenger-type apparatus, with the same glassware than conventional HD. A quantity of $500 \mathrm{~g}$ of sawdust was immersed in $9 \mathrm{~L}$ of distilled water and then continuously agitated with a stainless steel stirrer at $200 \mathrm{rpm}$ during $320 \mathrm{~min}$. Isolated oil was collected, dried over anhydrous sodium sulfate, and stored at $4^{\circ} \mathrm{C}$ until used. Each extraction was repeated at least three times for calculation of standard deviation.

\subsubsection{Solvent-free microwave extraction (SFME) and} $M H G$ methods and apparatus. SFME (Figure 2a) and MHG (Figure 2b) extractions were performed on a Milestone Ethos microwave laboratory oven. It is a multimode microwave reactor $2.45 \mathrm{GHz}$ with a maximum delivered power of $1000 \mathrm{~W}$ variable by $10 \mathrm{~W}$ increments. Temperature was monitored by an external infrared (IR) sensor. In a typical procedure of both methods performed at atmospheric pressure, a quantity of $200 \mathrm{~g}$ of maritime pine sawdust waste was heated using a fixed power of $600 \mathrm{~W}$ for $180 \mathrm{~min}$. For SFME, the microwave heating of water contained inside raw material allowed releasing molecules constituting isolated oil. This oil was then driven by generated vapor. A cooling system outside the microwave cavity permitted to condensate the distillate continuously. Condensed water was refluxed to extraction vessel in order to provide uniform conditions of temperature and humidity. For MHG, a mixture of hot "crude extracted oil" and vapor (in situ water) moved naturally downward by gravity on a spiral condenser outside microwave cavity where it condensed. The oily condensate was collected continuously in a

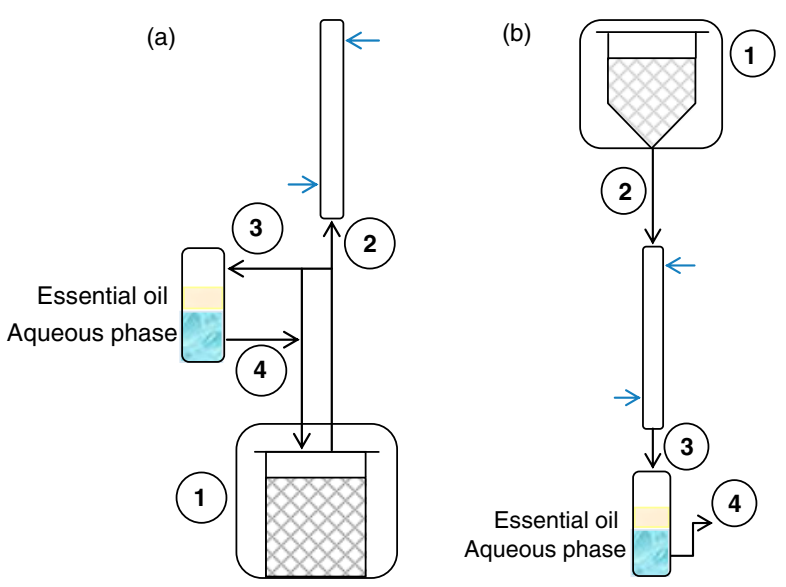

Figure 2. SFME (a) and MHG (b) apparatus. 1: microwave oven; 2: evaporation; 3: separation; 4 (a): water reflux; 4 (b): waste water. receiving flask where oil formed a film on the surface of water. The film was then skimmed off on the top. Both extractions were achieved at $100^{\circ} \mathrm{C}$ until no more oil was obtained. The oil was collected, dried under anhydrous sodium sulfate, and stored at $4^{\circ} \mathrm{C}$ until used. Each extraction was performed three times.

2.2.4 Procedure and apparatus of UAE. UAE was carried out using an ultrasonic device operating at low frequencies $(20 \mathrm{kHz})$ with $1000 \mathrm{~W}$ ultrasonic processor (UIP1000hd, Hielscher Ultrasonics, $\mathrm{GmbH}$, Germany). The computer-supported control of ultrasonic processor was operated by UPCCTRL V3.2 WIN software. This program allows the pre-adjustment of pulse and amplitude of ultrasonic processor control parameters. A stirrer was added to homogenize the solid-liquid mixing. A quantity of $500 \mathrm{~g}$ of maritime sawdust waste was pretreated by ultrasound during $15 \mathrm{~min}$ at an ultrasonic power of $300 \mathrm{~W}$, and each sample was treated in the same glassware and the same operating conditions as those of conventional HD procedure (Section 2.2.1). Each extraction was performed three times.

\subsection{Gas Chromatography Coupled to Mass Spectrometry (GC-MS) identification}

Volatile compounds were analyzed by GC-MS on QP2010 (Shimadzu, Kyoto) apparatus, using Elite $5 \mathrm{MS}$ nonpolar column was used $(30 \mathrm{~m} \times 0.25 \mathrm{~mm} \times$ $0.25 \mu \mathrm{m}$ film thickness). GC-MS spectra were obtained using following conditions: carrier gas $\mathrm{He}$; flow rate $35 \mathrm{~cm} \mathrm{~s}^{-1}$; split 1:20; injection volume $1 \mu \mathrm{l}$; injection temperature $250^{\circ} \mathrm{C}$; oven temperature range progressed from 50 to $240^{\circ} \mathrm{C}$ at $2^{\circ} \mathrm{C} \mathrm{min}{ }^{-1}$; ionization mode used was electronic impact at 70 $\mathrm{eV}$, and the scanning from 35 to 350 uma at 3 scan $\mathrm{s}^{-1}$. Most constituents were tentatively identified by comparison of their GC linear retention indices (RI), determined with reference to homologous series of C7-C30 n-alkanes. The identification was confirmed by comparison of mass spectral with those stored in the MS database (National Institute of Standards and Technology NIST08 and Wiley libraries) and comparison of index retention (Adams 2007) on Elite 5MS.

\subsection{BET surface area}

The assessment of specific surface area is an important criterion for a further valorization of the solid residue. In this study, all specific surface area measurements were performed with an Accelerated Surface Area and Porosymetry analyzer (ASAP 
2020, Micrometritics Instrument Corp). The specific surface area of raw wood being less than $1 \mathrm{~cm} 2 /$ $\mathrm{g}$, analyses were performed with krypton $(\mathrm{Kr})$ as gas adsorbate at liquid nitrogen temperature $(77 \mathrm{~K})$. All samples were degassed at $30^{\circ} \mathrm{C}$ under vacuum lesser than $10 \mu \mathrm{m} \mathrm{Hg}$ prior to measurements to remove adsorbed water. The specific surface area was calculated on Brunauer, Emmett and Teller (BET) equation (Brunauer et al. 1938) from the linear part of the adsorption isotherm, at pressure $0.05<P / P_{0}<$ 0.30 (where $P$ is the equilibrium pressure and $P_{0}$ is the saturation pressure). Each measure was repeated at least five times to calculate the standard deviation.

\section{Results and discussion}

\subsection{Kinetics of $H D$, THD, UAE, SFME, and $M H G$} isolation techniques

Figures 3 and 4 compare the extraction kinetics of classical HD with that of intensified extraction methods THD, UAE, SFME, and MHG. It appears that the maximum extraction yield for THD was reached for $180 \mathrm{~min}$, while for $\mathrm{HD}$, the maximum was obtained for $480 \mathrm{~min}$ processing time (Table I). For all isolation techniques, the maximum varied between $0.26 \%$ and $0.28 \%$. These values are in agreement with those of Dob et al. (2005). 0.3\% for extraction of essential oil from Mediterranean $P$. pinaster in the form of needles. The effect of agitation and subsequent cutting causes the loosing of tenacious and fibrous wood microstructure, resulting in an enlarged contact with water. PérinoIssartier et al. (2010) compared the effect of microwave heating with a process combining microwave heating and THD for isolation of essential oil from Schinus terebinthifolius Raddi Berries which also have a tenacious structure. They concluded that this intensified extraction process enabled substantial savings in energy and time. From Figure 3, it can be seen that the kinetics of UAE had almost the same behavior as that of THD. Compared to conventional $\mathrm{HD}$, sonication induced by UAE extraction process improved significantly the time necessary to reach maximum yield; $150 \mathrm{~min}$ for UAE instead of $480 \mathrm{~min}$ for HD while extraction technique used did not influence the quantity of

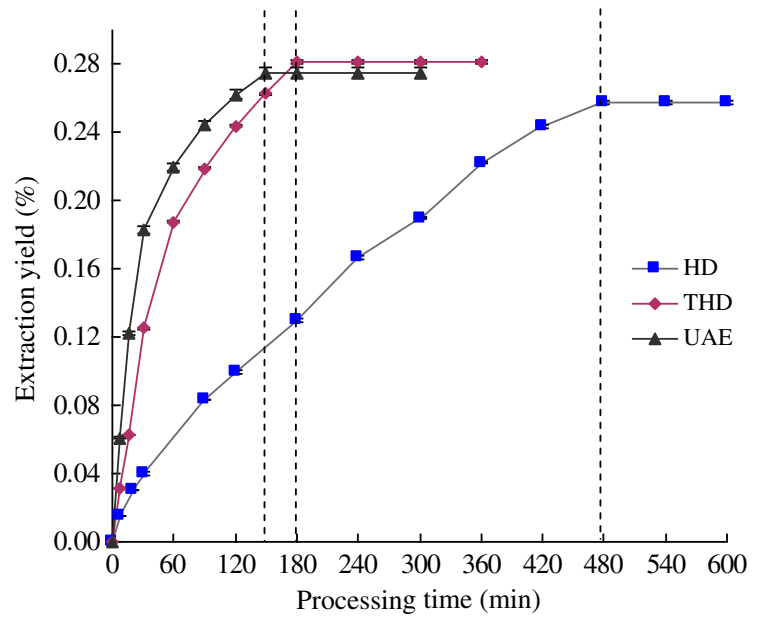

Figure 3. Kinetics of oil isolated by UAE and THD compared to $\mathrm{HD}$.

extracts recovered. These results are in agreement with those of St-Pierre et al. (2013) who compared two methods for extracting polyphenols from Canadian wood (Acer saccharum and Betula alleghaniensis): ultrasound and solvent maceration. The authors concluded that both extraction methods yielded similar results, while the advantage of ultrasoundassisted method was a shorter extraction time. The depolymerization process that occurred through a cavitation could involve two possible mechanisms: mechanical degradation of polymer from collapsed cavitation bubble and releasing some chemicals issued from reactions between the polymer and high-energy molecules such as hydroxyl radicals produced from cavitation phenomenon (Chemat et al. 2011). Lower extraction times ( 60 $\mathrm{min})$ to reach the maximum yield were obtained for SFME and MHG (Table I). The rate of oil extraction was assumed to obey a first-order kinetic law, an assumption supported by various authors (Spiro and Chong 1997). In integrated form, the kinetics are described by Equation 1,

$$
\ln \left(\frac{y_{\infty}}{y_{\infty}-y(t)}\right)=k_{i} t+a
$$

Table I. Yield, extractions times, and the kinetic constants in the first step $(k)$ for the different isolation techniques used. The yield was measured at the end of the first step.

\begin{tabular}{lccccc}
\hline & HD & THD & UAE & SFME & MHG \\
\hline Yield $(\% \mathrm{w} / \mathrm{w})$ & $0.258 \pm 0.002$ & $0.282 \pm 0.003$ & $0.275 \pm 0.003$ & $0.272 \pm 0.003$ & $0.266 \pm 0.002$ \\
Extraction time (min) & 480 & 180 & 150 & 60 & 60 \\
$\mathrm{k}\left(\mathrm{min}^{-1}\right)$ & 0.005 & 0.0178 & 0.0239 & 0.0426 & 0.0492 \\
\hline
\end{tabular}




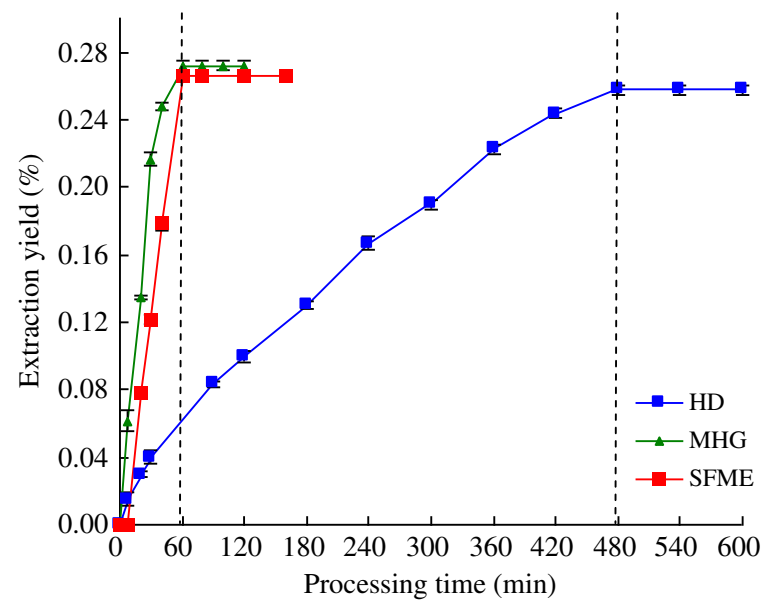

Figure 4. Kinetics of oil isolated by SFME and MHG compared with HD.

where ${ }_{\infty}^{y}$ is the extraction yield at the end of process, $y(t)$ the yield of extraction at time $t, k_{i}$ a first-order rate constant, and "a" the semiempirical intercept. For all techniques tested, extraction occurred in two kinetic steps. From Figures 3 and 4, it is clear that the first step consist in a rapid increase in yield followed by a second step corresponding to an almost horizontal line which marks the end of the extraction procedure. The kinetic constants in the first step $(k)$ followed this order (Table I): HD $<$ $\mathrm{THD}<\mathrm{UAE}<\mathrm{SFME}<\mathrm{MHG}$. For SFME and MHG, the high kinetic constants suggested that the volatile molecules were sensitive to irradiation power which determined the rate of water evaporation or the mixture of water and volatile compounds. Regarding mass transfer in $\mathrm{HD}$, it is well known that it takes place from inside to the outside while heat transfer occurs from the outside to inside. A different mechanism was proposed (Bousbia et al. 2009) for microwave isolation process in which the two transport phenomena are in the same direction from inside material to the outside. The acceleration of extraction rate is probably due to a synergetic combination of mass and heat transfers that act in the same direction.

\subsection{Composition of isolated oil}

Table II summarizes retention time, content, relative percentage of constituent's classes of oils obtained from maritime pine wood waste for all used isolation processes. All oils obtained had a light yellow color and had a pleasant pine smell. Regardless the extraction method, the dominant group of components of maritime pine wood oil was the same: sesquiterpenes hydrocarbon and especially $\beta$-caryophyllene. A higher relative amount of $\beta$-caryophyllene was detected for THD (26.0\%) and HD (22.2\%) compared to UAE
(18.0\%), SFME (16.6\%), and MHG (11.2\%). These results are very interesting since a same percentage of $\beta$-caryophyllene $(26.6 \%)$ was cited by Dob et al. (2005) for oil isolated by HD of Mediterranean $P$. pinaster in the form of needles while in this study a wood by-product was used. Higher amounts of total oxygenated compounds were present in oils extracted by microwave processes: $56.9 \%$ for MHG and $54.5 \%$ for SFME compared to $44.1 \%, 37.7 \%$, and $34.1 \%$, respectively, for UAE, THD, and HD (Figure 5). According to extraction method used, it would be possible to favor the antibacterial activity of the oil through $\beta$-caryophyllene compound (HD and THD) or the antioxydant activity which is related to a high percentage of oxygenated compounds (MHG and SFME) (Li et al. 2012). The oxygenated compounds are more valuable in the essential oils with a strong odor as characteristic. Their abundance in oils obtained by MHG, SFME, and in a lesser extent by UAE can be related to the rapid heating of polar substances by microwaves or ultrasonic power in presence of small amount of water compared to HD or THD isolation processes for which wood is immersed in water. This rapid heating would prevent the degradation of compounds by thermal and hydrolytic effects. Moreover, organic compounds like oxygenated compounds with a high dipolar moment interact more vigorously with microwaves and can be extracted easily, conversely to aromatic compounds (like monoterpene hydrocarbons) which have a low dipolar moment. According to these results, it seems that the phenomenon called "hydrodiffusion" and the mechanism described by Von Rechenberg (1910) which stipulates that "the compounds vaporize according to their degree of solubility in the distillation water rather than following the order of their boiling point" is more pronounced in the case of microwave extraction-distillation. In fact, oxygenated compounds with the highest boiling point are predominant in both SFME and MHG extracts.

\subsection{Structural impact of the different extraction processes}

Increasing of specific surface area (SSA) of treated samples is clearly visible for HD, THD, and UAE extractions (Table III). The highest values of SSA were obtained for HD and THD, with: $0.61 \pm 0.01$ $\mathrm{m}^{2} / \mathrm{g}$ and $0.71 \pm 0.02 \mathrm{~m}^{2} / \mathrm{g}$, respectively, compared with $0.45 \pm 0.02 \mathrm{~m}^{2} / \mathrm{g}$ for untreated raw material. This difference is lesser for UAE wood sample with SSA of $0.59 \pm 0.02 \mathrm{~m}^{2} / \mathrm{g}$. The rising of SSA is probably due to the solubilisation and/or evaporation phenomena which normally increases the exchange surface. The samples treated by MHG and SFME had a similar low value of SSA of $0.40 \pm 0.01 \mathrm{~m}^{2} / \mathrm{g}$, which confirm the specific effect of microwave 
Table II. Chemical composition of maritime pine wood oil obtained by HD, THD, MHG, and UAE.

\begin{tabular}{|c|c|c|c|c|c|c|}
\hline \multirow[b]{2}{*}{ Compound $^{\mathrm{a}}$} & \multirow[b]{2}{*}{$\mathrm{Ri}^{\mathrm{b}}$} & \multicolumn{5}{|c|}{ Compound $(\%) \pm \mathrm{SD}^{\mathrm{c}}$} \\
\hline & & $\mathrm{HD}$ & THD & MHG & SFME & UAE \\
\hline Monoterpene hydrocarbons & & $12.4 \%$ & $6.6 \%$ & $0.6 \%$ & $1.6 \%$ & $16.2 \%$ \\
\hline$\alpha$-Pinene & 928 & $8.2 \pm 0.4$ & $2.6 \pm 0.6$ & $0.2 \pm 0.1$ & $0.6 \pm 0.1 \%$ & $5.2 \pm 0.3$ \\
\hline Camphene & 943 & - & $0.1 \pm 0.1$ & - & - & - \\
\hline$\beta$-Pinene & 972 & $3.2 \pm 0.2$ & $2.0 \pm 0.3$ & $0.1 \pm 0.1$ & $0.3 \pm 0.1$ & $3.3 \pm 0.1$ \\
\hline$\beta$-Myrcene & 987 & - & - & - & - & $0.1 \pm 0.1$ \\
\hline$\Delta$-3-Carene & 1006 & $0.2 \pm 0.1$ & $0.7 \pm 0.1$ & $0.1 \pm 0.1$ & $0.2 \pm 0.1$ & $0.3 \pm 0.1$ \\
\hline Limonene & 1025 & $0.7 \pm 0.1$ & $0.8 \pm 0.1$ & $0.1 \pm 0.1$ & $0.3 \pm 0.1$ & $6.9 \pm 0.5$ \\
\hline$\alpha$-Terpinolene & 1081 & $0.1 \pm 0.1$ & $0.3 \pm 0.1$ & $0.1 \pm 0.1$ & $0.2 \pm 0.1$ & $0.3 \pm 0.1$ \\
\hline$p$-Cymenene & 1086 & - & $0.1 \pm 0.1$ & - & - & $0.1 \pm 0.1$ \\
\hline Oxygenated monoterpenes & & $3.4 \%$ & $17.8 \%$ & $14.8 \%$ & $13.7 \%$ & $16.9 \%$ \\
\hline Fenchone & 1084 & $0.1 \pm 0.1$ & $0.6 \pm 0.2$ & - & - & $0.2 \pm 0.1$ \\
\hline Linalool & 1099 & $0.1 \pm 0.1$ & $0.1 \pm 0.1$ & $0.5 \pm 0.1$ & $0.3 \pm 0.1$ & $0.4 \pm 0.1$ \\
\hline Fenchol & 1115 & $0.1 \pm 0.1$ & $0.4 \pm 0.1$ & $0.5 \pm 0.1$ & $0.9 \pm 0.2$ & $0.9 \pm 0.1$ \\
\hline Camphor & 1141 & $0.3 \pm 0.1$ & $1.1 \pm 0.2$ & $0.1 \pm 0.1$ & $0.1 \pm 0.1$ & $0.4 \pm 0.1$ \\
\hline Borneol & 1166 & $0.2 \pm 0.1$ & $0.7 \pm 0.1$ & $1.5 \pm 0.2$ & $1.5 \pm 0.3$ & $1.4 \pm 0.2$ \\
\hline Terpin-4-ol & 1175 & $0.3 \pm 0.2$ & $2.1 \pm 0.3$ & $1.5 \pm 0.2$ & $1.6 \pm 0.2$ & $2.4 \pm 0.2$ \\
\hline$\alpha$-Terpineol & 1191 & $2.1 \pm 0.2$ & $12.4 \pm 0.6$ & $10.0 \pm 0.4$ & $8.8 \pm 0.5$ & $10.7 \pm 0.4$ \\
\hline Linalyl acetate & 1248 & - & $0.1 \pm 0.1$ & $0.5 \pm 0.1$ & $0.3 \pm 0.1$ & $0.2 \pm 0.1$ \\
\hline$\alpha$-Terpinyl acetate & 1342 & $0.2 \pm 0.1$ & $0.3 \pm 0.1$ & $0.2 \pm 0.1$ & $0.2 \pm 0.1$ & $0.3 \pm 0.1$ \\
\hline Ester & & $0.1 \%$ & $0.4 \%$ & $5.0 \%$ & $3.6 \%$ & $2.8 \%$ \\
\hline Estragole & 1193 & $0.1 \pm 0.1$ & $0.4 \pm 0.1$ & $0.3 \pm 0.1$ & $0.3 \pm 0.1$ & $0.3 \pm 0.1$ \\
\hline Anethol & 1281 & - & - & $4.7 \pm 0.3$ & $3.3 \pm 0.4$ & $2.5 \pm 0.3$ \\
\hline Sesquiterpene hydrocarbons & & $53.5 \%$ & $55.4 \%$ & $42.4 \%$ & $43.7 \%$ & $39.6 \%$ \\
\hline$\alpha$-Longipinene & 1341 & $0.9 \pm 0.2$ & $1.1 \pm 0.2$ & $0.7 \pm 0.1$ & $0.2 \pm 0.1$ & $0.7 \pm 0.1$ \\
\hline$\alpha$-Terpinyl acetate & 1342 & $0.2 \pm 0.1$ & $0.3 \pm 0.1$ & $0.2 \pm 0.1$ & $0.1 \pm 0.1$ & $0.3 \pm 0.1$ \\
\hline$\alpha$-Copaene & 1368 & $0.8 \pm 0.2$ & $1.4 \pm 0.1$ & $0.5 \pm 0.1$ & $0.4 \pm 0.2$ & $0.8 \pm 0.1$ \\
\hline Longifolene & 1397 & $15.6 \pm 0.6$ & $12.6 \pm 0.5$ & $14.6 \pm 0.6$ & $14.1 \pm 0.4$ & $7.9 \pm 0.5$ \\
\hline$\beta$-Caryophyllene & 1409 & $22.2 \pm 1.0$ & $26.0 \pm 1.1$ & $11.2 \pm 0.9$ & $16.6 \pm 0.9$ & $18.0 \pm 1.1$ \\
\hline$\alpha$-Caryophyllene & 1445 & $7.7 \pm 0.4$ & $5.2 \pm 0.4$ & $8.8 \pm 0.3$ & $6.3 \pm 0.2$ & $4.4 \pm 0.4$ \\
\hline$\beta$-Cadinene & 1463 & $0.5 \pm 0.1$ & $0.4 \pm 0.1$ & $0.6 \pm 0.1$ & $0.7 \pm 0.2$ & $0.5 \pm 0.1$ \\
\hline$\gamma$-Muurolen & 1467 & $0.8 \pm 0.1$ & $1.3 \pm 0.1$ & $0.9 \pm 0.1$ & $1.3 \pm 0.1$ & $0.9 \pm 0.2$ \\
\hline Germacrene D & 1471 & $0.5 \pm 0.1$ & $0.7 \pm 0.1$ & $0.3 \pm 0.1$ & $0.1 \pm 0.1$ & $0.7 \pm 0.1$ \\
\hline$\alpha$-Muurolen & 1490 & $1.6 \pm 0.3$ & $2.9 \pm 0.2$ & $1.6 \pm 0.2$ & $2.1 \pm 0.3$ & $1.9 \pm 0.3$ \\
\hline$\Delta$-Cadinene & 1510 & $2.7 \pm 0.3$ & $3.5 \pm 0.3$ & $3.0 \pm 0.3$ & $1.8 \pm 0.2$ & $3.5 \pm 0.4$ \\
\hline Oxygenated sesquiterpenes & & $16.5 \%$ & $12.5 \%$ & $7.2 \%$ & $6.4 \%$ & $9.7 \%$ \\
\hline Trans nerolidol & 1557 & $1.3 \pm 0.2$ & $0.9 \pm 0.1$ & $0.5 \pm 0.1$ & $0.6 \pm 0.2$ & $1.1 \pm 0.3$ \\
\hline Caryophyllene oxide & 1569 & $3.4 \pm 0.5$ & $4.7 \pm 0.3$ & $1.4 \pm 0.2$ & $1.4 \pm 0.4$ & $3.1 \pm 0.3$ \\
\hline Longiborneol & 1587 & $1.0 \pm 0.2$ & $1.0 \pm 0.2$ & $0.7 \pm 0.1$ & $0.6 \pm 0.1$ & $0.9 \pm 0.1$ \\
\hline Sesqui(222) & 1617 & $1.2 \pm 0.2$ & $1.0 \pm 0.2$ & $0.9 \pm 0.1$ & $0.7 \pm 0.1$ & $1.2 \pm 0.2$ \\
\hline Sesqui (222) & 1631 & $0.8 \pm 0.1$ & $0.7 \pm 0.1$ & $0.6 \pm 0.1$ & $0.5 \pm 0.1$ & $0.8 \pm 0.1$ \\
\hline$\Delta$-Cadinol & 1636 & $0.7 \pm 0.1$ & $0.6 \pm 0.1$ & $0.5 \pm 0.1$ & $0.5 \pm 0.1$ & $0.7 \pm 0.1$ \\
\hline$\alpha$-Cadinol & 1644 & $1.1 \pm 0.2$ & $0.6 \pm 0.1$ & $0.6 \pm 0.1$ & $0.6 \pm 0.1$ & $0.8 \pm 0.1$ \\
\hline Patchouli alcohol & 1652 & $6.3 \pm 0.4$ & $2.6 \pm 0.2$ & $1.4 \pm 0.2$ & $0.9 \pm 0.2$ & $0.4 \pm 0.1$ \\
\hline$\alpha$-Atlantone & 1764 & $0.7 \pm 0.1$ & $0.4 \pm 0.1$ & $0.6 \pm 0.1$ & $0.6 \pm 0.2$ & $0.7 \pm 0.1$ \\
\hline Other oxygenated compounds & & $14.1 \%$ & $7.0 \%$ & $29.9 \%$ & $30.8 \%$ & $14.7 \%$ \\
\hline Manoyl oxide & 1993 & $0.7 \pm 0.2$ & $0.8 \pm 0.1$ & $1.9 \pm 0.2$ & $1.9 \pm 0.3$ & $1.1 \pm 0.2$ \\
\hline Iso cembrol & 2024 & $0.2 \pm 0.1$ & $0.7 \pm 0.1$ & $1.3 \pm 0.2$ & $1.2 \pm 0.1$ & $1.1 \pm 0.1$ \\
\hline Manool & 2035 & $2.5 \pm 0.4$ & $1.3 \pm 0.2$ & $4.3 \pm 0.4$ & $4.9 \pm 0.5$ & $2.4 \pm 0.2$ \\
\hline 13(16),14-Labdien-8-ol & 2084 & $1.3 \pm 0.2$ & $0.5 \pm 0.1$ & $2.3 \pm 0.2$ & $2.9 \pm 0.2$ & $1.0 \pm 0.1$ \\
\hline (12Z)-Abienol & 2127 & $2.7 \pm 0.2$ & $0.8 \pm 0.1$ & $6.5 \pm 0.5$ & $6.6 \pm 0.4$ & $2.2 \pm 0.3$ \\
\hline Primaral & 2138 & $3.8 \pm 0.3$ & $1.8 \pm 0.3$ & $8.4 \pm 0.8$ & $8.4 \pm 0.4$ & $3.9 \pm 0.3$ \\
\hline Pimara-7,15-dien-3-ol & 2195 & $2.3 \pm 0.3$ & $0.7 \pm 0.1$ & $3.7 \pm 0.3$ & $3.5 \pm 0.3$ & $2.2 \pm 0.2$ \\
\hline Kaura-5,16-dien-18(or 19)-ol & 2207 & $0.6 \pm 0.2$ & $0.4 \pm 0.1$ & $1.5 \pm 0.1$ & $1.4 \pm 0.2$ & $0.8 \pm 0.1$ \\
\hline Total oxygenated compounds & & $34.1 \%$ & $37.7 \%$ & $56.9 \%$ & $54.5 \%$ & $44.1 \%$ \\
\hline Total non-oxygenated compounds & & $65.9 \%$ & $62.0 \%$ & $43.0 \%$ & $45.3 \%$ & $55.8 \%$ \\
\hline Total identified compounds & & $100.0 \%$ & $99.7 \%$ & $99.9 \%$ & $99.8 \%$ & $99.9 \%$ \\
\hline
\end{tabular}

${ }^{\mathrm{a}}$ Compounds are listed in order of their elution time from an Elite 5MS column.

${ }^{\mathrm{b}} \mathrm{Ri}=$ retention indices, determined on an Elite 5MS column using the homologous series of n-alkanes (C7-C30).

${ }^{\mathrm{c}} \mathrm{SD}=$ standard deviation calculated using three replicates. 
Wood Material Science and Engineering (2014), Vol. 9, n 2, p. 76-83, DOI: 10.1080/17480272.2014.881915

Journal homepage : http://www.tandfonline.com/loi/swoo20

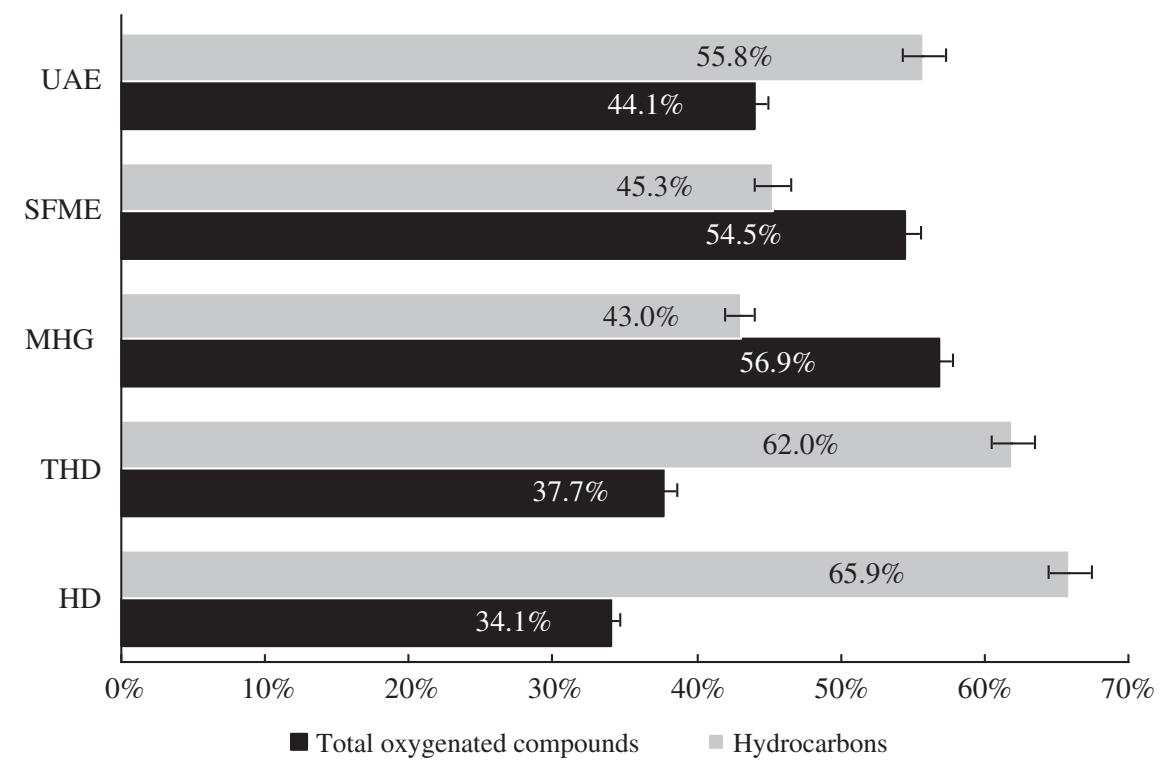

Figure 5. Comparative composition of maritime pine essential oils in terms of hydrocarbons and oxygenated compounds versus extraction processes.

Table III. Comparison of HD, THD, UAE, MHG, and SFME effects on specific area of maritime pine sawdust waste.

\begin{tabular}{lcccccc}
\hline & Raw & HD & THD & UAE & MHG & SFME \\
\hline Specific area $\left(\mathrm{m}^{2} / \mathrm{g}\right)$ & $0.45 \pm 0.02$ & $0.61 \pm 0.01$ & $0.71 \pm 0.02$ & $0.49 \pm 0.02$ & $0.4 \pm 0.01$ & $0.4 \pm 0.01$ \\
Extraction time $(\mathrm{min})$ & & 480 & 180 & 150 & 60 & 60 \\
\hline
\end{tabular}

treatment. This diminution could be due to the microwave treatment, which helps the evaporation instead of solubilisation as in conventional HD.

\subsection{Cost, energy, and environment ecology}

The proposed intensified extraction processes are clearly advantageous in terms of time and energy compared with conventional procedures such as steam distillation or hydrodistallation which are time and/or energy consuming and generally not always interesting from industrial point of view. According to extraction times and based on the same treated quantity of $500 \mathrm{~g}$, the energy required for UAE was $2.58 \mathrm{kWh}$ and that of SFME and MHG were $1.5 \mathrm{kWh}$ each, largely lower than energy required for THD and HD conventional extractions ( 8 and $4.8 \mathrm{kWh}$, respectively). Regarding the environmental impact, the quantities of $\mathrm{CO}_{2}$ rejected in atmosphere were $1.34 \mathrm{~kg}$ for SFME and MHG and $7.13,4.01$, and $2.30 \mathrm{~kg}$, respectively, for $\mathrm{HD}$, THD, and UAE. These calculations were preformed according to literature provided by the French Nuclear Energy Society (http://www.sfen.org/fr/societe/developpement/edf.htm): to obtain $1 \mathrm{kWh}$ from coal and fuel, respectively, 978 and $891 \mathrm{~g}$ of $\mathrm{CO}_{2}$ is rejected in atmosphere during combustion.

\section{Conclusion}

Different extraction methods were tested for isolation of volatiles from maritime pine wood sawdust waste and compared with classical HD method. It appeared that UAE, SFME, and MHG were more efficient than classical HD. It was showed that the isolation technique influences the extraction time, the composition of oil, and the structure of wood material after extraction. One can conclude that the short extraction time and subsequent low energy consumption of microwaves (MHG and SFME) processes and in a lesser extent UAE could be considered as original and environmentally friendly methods for the transformation of wood waste materials into valuable chemicals.

\section{Acknowledgments}

The financial support by "Région PoitouCharentes" through "VALBOIS" project is gratefully acknowledged.

\section{References}

Abert-Vian, M., Fernandez, X., Visinoni, F. and Chemat, F. (2008) Microwave hydrodiffusion and gravity, a new technique for extraction of essential oils. Fournal of Chromatography $A, 1190,14-17$. 
Adams, R. P. (2007) Identification of Essential Oil Components by Gas Chromatography/Mass Spectrometry, 4th ed. (Carol Stream, IL: Allured Publishing Corporation).

Bousbia, N., Abert-Vian, M., Ferhat, M. A., Meklati, B. Y. and Chemat, F. (2009) A new process for extraction of essential oil from Citrus peels: Microwave hydrodiffusion and gravity. Fournal of Food Engineering, 90, 409-413.

Brunauer, S., Emmett, P. H. and Teller, E. (1938) Adsorption of gases in multimolecular layers. Fournal of the American Chemical Society, 60, 309-319.

Chemat, F., Lucchesi, M. E., Favretto, L., Colnaghi, G. and Visinoni, F. (2006) Microwave accelerated steam distillation of essential oil from lavender: A rapid, clean and environmentally friendly approach. Analytica Chimica Acta, $555,157-160$.

Chemat, F., Vian, M. and Visinoni, F. (2008) Microwave hydrodiffusion for isolation of natural products. European patent, Application EP1955749 (A1).

Chemat, F., Zill-E-Huma and Khan, M. K. (2011) Applications of ultrasound in food technology: Processing, preservation and extraction. Ultrasonic Sonochemistry, 18, 813-835.

Dob, T., Berramdane, T. and Chelghoum, C. (2005) Analysis of essential oil from the needles of Pinus pinaster growing in Algeria. Chemistry of Natural Compounds, 41, 545-548.

European Pharmacopeia (2012) Online version. Accessed 14 June 2013, available at: http://online6.edqm.eu/ep705/

Farhat, A., Ginies, C., Romdhane, M. and Chemat, F. (2009) Eco-friendly and cleaner process for isolation of essential oil using microwave energy. Experimental and theoretical study. Fournal of Chromatography A, 1216, 5077-5085.

Fornari, T., Vicente, G. V., Vázquez, E., García-Risco, M. R. and Reglero, G. (2012) Isolation of essential oil from different plants and herbs by supercritical fluid extraction. Fournal of Chromatography A, 1250, 34-48.

Khajeh, M., Yamini, Y., Sefidkon, F. and Bahrafimar, N. (2004) Comparison of essential oil composition of Carum copticum obtained by supercritical carbon dioxide extraction and HD methods. Food Chemistry, 86, 587-591.

Lazutka, J. R., Mierauskene, J., Slapšytè, G. and Dedonytè, V. (2001) Genotoxicity of dill (Anethum graveolens L.), peppermint (Menthaxpiperita L.) and pine (Pinus sylvestris L.) essential oils in human lymphocytes and Drosophila melanogaster. Food Chemical Toxicology, 39, 485-492.

Li, X. J., Wang, W., Luo, M., Li, C. Y., Zu, Y. G., Mu, P. S. and Fu, Y. J. (2012) Solvent-free microwave extraction of essential oil from Dryopteris fragrans and evaluation of antioxidant activity. Food Chemistry, 133, 437-444.

Lucchesi, M. E., Smadja, J., Bradshaw, S., Louw, W. and Chemat, F. (2007) Solvent free microwave extraction of Elettaria cardamomum L.: A multivariate study of a new technique for the extraction of essential oil. Fournal of Food Engineering, 79, 1079-1086.

Marongiu, B., Piras, A., Porcedda, S. and Tuveri, E. (2006) Extraction of Santalum album and Boswellia carterii Birdw. volatile oil by supercritical carbon dioxide: Influence of some process parameters. Flavour and Fragrance fournal, 21, 718-724.

Mazzutti, S., Ferreira, S. R. S., Riehl, C. A. S., Smania, Jr A., Smania, F. A. and Martínez, J. (2012) Supercritical fluid extraction of Agaricus brasiliensis: Antioxidant and antimicrobial activities. Fournal of Supercritical Fluids, 70, 48-56.

Mellouk, H., Meullemiestre, A., Maache-Rezzoug, Z., Allaf, K. and Rezzoug, S. A. (2013) Isolation of volatiles from oak wood (Quercus alba) by a thermomechanical process: Screening of some processing parameters. Separation Science and Technology, 48, 1851-1858.
Moldão-Martins, M., Palavra, A., Beirão da Costa, M. L. and Bernardo-Gil, M. G. (2000) Supercritical $\mathrm{CO}_{2}$ extraction of Thymus zygis L. subsp. sylvestris aroma. Fournal of Supercritical Fluids, 18, 25-34.

Périno-Issartier, S., Abert-Vian, M., Petitcolas, E. and Chemat, F. (2010) Microwave turbo hydrodistillation for rapid extraction of the essential oil from Schinus terebinthifolius raddi berries. Chromatographia, 72, 347-350.

Priscilla, C., Veggi, P. C., Rodrigo, N., Cavalcanti, R. N. and Meireles, M. A. A. (2011) Modifier effects on Supercritical Fluid Extraction (SFE) of some Brazilian plants: Antioxidant activity and Economical evaluation. Procedia Food Science, 1, $1717-1724$

Rezzoug, S. A. (2009) Optimisation of steam extraction of oil from maritime pine needles. Fournal of wood Chemistry and Technology, 29, 87-100.

Rodríguez-Rojo, S., Visentin, A., Maestri, D. and Cocero, M. J. (2012) Assisted extraction of rosemary antioxidants with green solvents. Fournal of Food Engineering, 109, 98-103.

Sacchetti, G., Maietti, S., Muzzoli, M., Scaglianti, M. Manfredini, S., Radice, M. and Bruni, R. (2005) Comparative evaluation of 11 essential oils of different origin as functional antioxidants, antiradicals and antimicrobials in foods. Food Chemistry, 91, 621-632.

Sahraoui, N., Abert-Vian M., Bornard, I., Boutekedjiret, C. and Chemat, F. (2008) Improved microwave steam distillation apparatus for isolation of essential oils. Comparison with conventional steam distillation. fournal of Chromatography $A$, $1210,229-233$.

Sahraoui, N., Abert-Vian, M., El Maataoui, M., Boutekedjiret, C. and Chemat, F. (2011) Valorization of citrus by-products using Microwave Steam Distillation (MSD). Innovative Food Science and Emerging Technologies, 12, 163-170.

Seabra, I. J., Dias, A. M. A., Braga, M. E. M. and De Souza, H. C. (2012) Effect of solvent $\left(\mathrm{CO}_{2} /\right.$ ethanol/ $\left./ \mathrm{H}_{2} \mathrm{O}\right)$ on the fractionated enhanced solvent extraction of anthocyanins from elderberry pomace. Fournal of Supercritical Fluids, 62, 135-148.

Shirsatha, S. R., Sonawanea, S. H. and Gogate, P. R. (2012) Intensification of extraction of natural products using ultrasonic irradiations - A review of current status. Chemical Engineering and Processing, 53, 10-23.

Spiro, M. and Chong, Y. Y. (1997) The kinetics and mechanism of caffeine infusion from coffee: The temperature variation of the hindrance factor. Fournal of the Science of Food and Agriculture, 74, 416-420.

St-Pierre, F., Achim, A. and Stevanovic, T. (2013) Composition of ethanolic extracts of wood and bark from Acer saccharum and Betula alleghaniensis trees of different vigor classes. Industrial Crops and Products, 41, 179-187.

Tigrine-Kordjani, N., Meklati, B. Y. and Chemat, F. (2011) Contribution of microwave accelerated distillation in the extraction of the essential oil of Zygophyllum album $\mathrm{L}$. Phytochemical Analysis, 22, 1-9.

Vemavarapu, C., Matthew, J., Mollan, M. J., Lodaya, M. and Needham, T. E. (2005) Design and process aspects of laboratory scale SCF particle formation systems. International Fournal of Pharmaceutics, 292, 1-16.

Von Rechenberg, C. (1910) Theorie der gewinnung und trennung der ätherischen öle [Theory of extraction and separation of essential oils] (Berlin: Selbstverlag, Von Schimmel \& Co).

Willför, S., Ali, M., Karonen, M., Reunanen, M., Arfan, M. and Harlamow, R. (2009) Extractives in bark of different conifer species growing in Pakistan. Holzforschung, 63, 551-558. 